\title{
Penerapan Animasi 3 Dimensi Untuk Wisata Edukasi Anak Berbasis Virtual Reality
}

\author{
Syahrir $^{1)}$,Adelya Putri Restika ${ }^{2)}$, Muhammad Naufal ${ }^{3)}$, Multazam Firdaus ${ }^{4)}$ \\ 1)2)3)4)Jurusan Teknik Elektro,Politeknik Negeri Ujung Pandang \\ Email: syahrir@poliupg.ac.id ${ }^{1)}$,adelyaputrirestika@gmail.com ${ }^{2)}$,naufalrezki30@gmail.com ${ }^{3)}$, \\ azzamdaus55@gmail.com ${ }^{4)}$
}

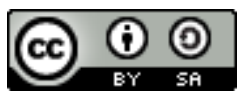

\begin{abstract}
Abstrak
Wisata edukasi atau wisata pendidikan bertujuan untuk meningkatkan kecerdasan dan kreatifitas peserta kegiatan wisata. Manfaat wisata edukasi untuk anak ialah menumbuhkan semangat belajar,mendidik anak mempraktikan ilmu,merangsang saraf motorik anak. Dengan berkembangnya teknologi,Virtual Reality bisa menjadi salah satu perangkat untuk membantu wisata edukasi lebih menarik lagi,ini dikarenakan Virtual Reality dapat memberikan sensasi dunia nyata dalam dunia maya dan pengguna dapat berinteraksi dengan lingkungan yang ada di dalam dunia maya yang di simulasikan oleh komputer.
\end{abstract}

Kata kunci: Wisata edukasi, Virtual reality

\section{PENDAHULUAN}

Wisata pendidikan adalah suatu kegiatan atau perjalanan yang dilakukan untuk rekreasi atau liburan dan juga terdapat aktivitas edukasi atau pendidikan didalamnya (Rodger,1998). Ada banyak kegiatan wisata edukasi yang bisa di lakukan khususnya bagi anak-anak yang masih membutuh pembelajaran akan dunia luar. Biasanya tujuan wisata edukasi adalah tempat-tempat yang memiliki nilai tambah sebagai sebuah area wisata, seperti kawasan perkebunan, kebun binatang, tempat penangkaran hewan langka, pusatpusat penelitian dan lain sebagainya.

Namun, saat ini masyarakat khususnya kaum orang tua masih bingung mencari tempat wisata edukasi buat anak- anak mereka. Untuk daerah makassar sendiri wisata edukasi buat anak-anak masih belum ada. Hal ini sesuai yang di ungkapkan mitra usaha PT Ekowisata Butta Gowa Resort yang mempunyai pengunjung wisata sebanyak 200 sampai 300 pengunjung wisata per bulan. Dari hasil wawancara penulis dengan mitra usaha mengukapkan bahwa permasalahan mitra adalah belum mempunyai spot area wisata edukasi padahal jumlah pengunjung wisata di tempatnya rata -rata

$40 \%$ masih anak-anak. Padahal keberadaan spot wisata edukasi sangat di butuhkan anak-anak dan hal ini juga bisa menambah jumlah pengunjung di tempat ekowisata butta gowa resort. Permasalahan belum adanya tempat wisata edukasi dikarenakan lingkungan ekowisata yang tidak luas dan banyak terdapat batuan gunung sehingga belum cocok dijadikan sebagai area wisata edukasi dan juga memerlukan modal anggaran yang besar untuk membuat wisata edukasi. Oleh karena itu untuk mengatasi permasalahan mitra diatas maka penulis menawarkan penerapan teknologi untuk spot area wisata edukasi virtual dengan menggunakan teknologi animasi 3 dimensi berbasis virtual reality yang dapat diterapkan di PT.Ekowisata Butta Gowa Resort tanpa memerlukan lahan, tempat dan anggaran yang besar.

Teknologi animasi 3 dimensi menggunakan virtual reality ini memberikan suatu pengalaman kepada pengguna (user) anak-anak untuk merasakan pengalaman belajar diluar 
seperti belajar berkebun, mengunjungi kebun binatang, mengenal hewan purba, belajar Sains, matematika dan abjad sambil berwisata di dunia animasi seolaholah user anak-anak berada didunia nyata. Aplikasi ini akan mempermudah anakanak untuk lebih mengenal dan mendapatkan beberapa informasi dari objek-objek di dalamnya dengan aplikasi berbasis 3D.

\section{KAJIAN PUSTAKA}

Penelitian mengenai AR/VR telah banyak dilakukan oleh para peneliti. Khususnya studi pengalaman pengguna saat menggunakan sebagi AR/VR untuk pembalajaran. Seperti penerapan teknologi Augmented Reality pada media pembelajaran dengan metode dan perangkat yang digunakan adalah marker yang menggunakan buku panduan (ossy dwi endah wulansarai,dkk, 2013). Sistem AR tersebut dapat disajikan ke dalam buku ajar.

Sebuah sistem Game edukasi berbasis AR/VR juga pernah dikembangkan. Sistem yang dibuat memberikan permainan pameran selanjutnya melalui informasi multimedia. Sistem tersebut sangat bermanfaat dan mengakibatkan pengguna dapat belajar lebih banyak mengenal objek( Robby Wijaya Khoerniawan,dkk, 2018).

Studi penggunaan AR/VR untuk wisata pendidikan di museum juga pernah di kembangkan dimana museum merupakan tempat yang menarik untuk memperkenalkan AR/VR kepada pengunjung atau masyarakat umum. Pengamatan interaksi antara pengunjung museum dan perangkat yang digunakan bermanfaat untuk mengidentifikasi situasi ketika aplikasi AR/VR berguna dan relevan. Studi lain tentang kunjungan museum menyatakan bahwa kebergunaan (usefulness) dan kenikmatan (fun) adalah faktor penting saat menggunakan aplikasi AR mobile (Haugstvedt, 2012).
Pengenalan objek binatang dengan menggunakan teknologi AR/VR juga pernah dikembangkan dimana anak-anak bisa mempelajari jenis-jenis hewan seperti ikan( Gede Thadeo Angga Kusuma,2017). Pemanfaatan Augmented Reality/Virtual Reality untuk pemberdayaan wisata bawah laut juga pernah di kembangkan (Gede Rasben Dantes,2017). Tujuan pengembangan dari AR/VR ini untuk meningkatkan daya dukung parawisata dengan memberdayakan wisata bawah laut.

Teknologi AR/VR sangat potensial sebagai sarana edukasi. Salah satu keuntungan yang dapat diperoleh dari aplikasi AR/VR untuk tujuan edukasi yaitu meningkatkan pemahaman objek yang sedang dipelajari. AR/VR lebih efektif sebagai media pembelajaran lainnya. dibandingkan dengan media yang lain seperti buku, video, maupun penggunaan komputer biasa (Radu, 2012).

Dari hasil tinjauan pustaka ilmiah tersebut penulis akan memberikan solusi bagi mitra usaha ekowisata butta gowa resort tentang wisata edukasi bagi anakanak yang lebih lengkap berbasis aplikasi virtul reality. Aplikasi ini ini dilengkapi dengan panduan belajar berkebun, belajar mengenal hewan purba, belajar sains, belajar abjad dan belajar matematika dengan berwisata didunia animasi seperti seolah-olah berada didunia nyata. Wisata edukasi ini nantinya akan diterapkan pada anak yang berusia PAUD dan anak-anak sekolah dasar yang ingin belajar sambil berwisata. Aplikasi ini akan diletakkan dalam sebuat spot tempat ruangan yang akan disediakan oleh mitra usaha ekowisata butta gowa resort.

\section{METODE}

A. Gambaran Umum Sistem

Gambar 3.1. Menjelaskan alur dari pembuatan aplikasi yang akan dibuat. Langkah pertama yaitu membuat objek dari benda yang ada di ditempat wisata 
edukasi, menyiapkan file informasi untuk setiap benda yang dijadikan 3D, pencarian dan pembuatan gambar sehingga menjadi library marker. Data tahap awal digabungkan menjadi komponen utama projek aplikasi Virtual Reailty wisata edukasi menggunakan kacamata VR. Virtual Reality menghasilkan aplikasi yang mampu digunakan pada platform Android yang mampu digunakan langsung untuk mendeteksi marker, sehingga menghasilkan output berupa objek 3D dan informasi dari benda tersebut.

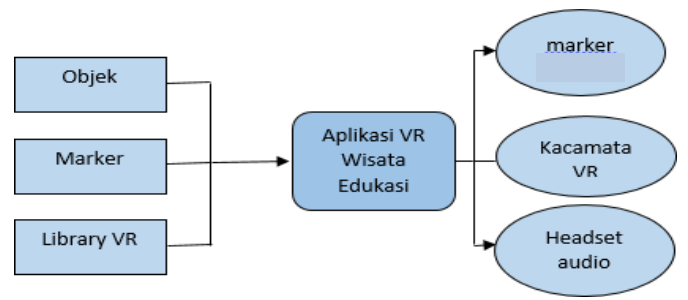

Gambar 3.1 Gambaran Umum Perancangan Aplikasi Virtual Reality Wisata Edukasi

\section{B. Diagram Activity Penggunaan Aplikasi}

Gambar 3.2. Menunjukkan secara umum alur kerja aplikasi Virtual Reality pada wisata edukasi. User menggunakan smartphone berbasis Android yang sudah ter-install aplikasi Virtual Reality pada tampilan splash screen muncul setelah user membuka aplikasi. Sistem selanjutnya menampilkan menu utama dari aplikasi. Menu utama memiliki pilihan informasi belajar yang bisa user pilih. User harus memilih salah satu informasi yang ingin dideteksi. Tampilan informasi wisata edukasi muncul setelah user memilih pilihan menu wisata edukasi yang diinginkan. Informasi wisata edukasi merupakan gambaran umum mengenai informasi belajar yang dipilih. Sistem kemudian membawa user ke tampilan utama kamera untuk mendeteksi marker. Sistem bekerja dengan mendeteksi marker yang tersedia pada buku marker atau bidang marker khusus yang sudah disediakan. Kamera diarahkan user pada ketinggian tertentu guna mendapatkan hasil deteksi yang maksimal. Sistem hanya memunculkan objek 3D sesuai dengan marker dari informasi objek yang dipilih. Satu marker mewakili satu pembelajaran yang terdapat di gedung yang sudah dibuat dalam bentuk 3D. Informasi mengenai objek 3D yang dimunculkan terdapat dalam bentuk tulisan dan suara.User dapat kembali ke menu utama sebelum benar-benar keluar dari aplikasi.

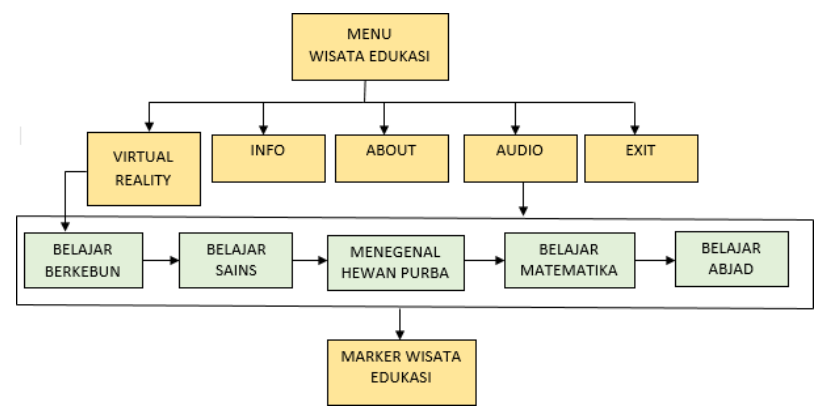

Gambar 3.2 Diagram Activity Aplikasi Virtual Reality Pada Wisata Edukasi

C. Use Case Diagram

Use Case Diagram digunakan untuk menggambarkan requirement fungsional dari aplikasi Virtual Reality Wisata Edukasi serta bagaimana aplikasi ini berinteraksi dengan user seperti gambar 3.3.

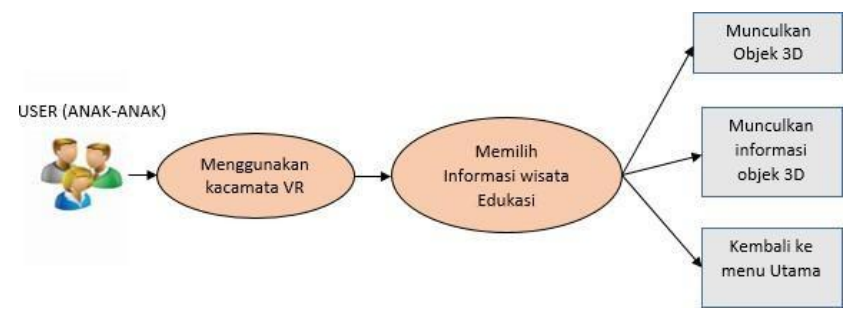

Gambar 3.3 Use Case Diagram Aplikasi Virtual Reality Wisata Edukasi

\section{HASIL DAN PEMBAHASAN}

1. Tampilan Menu Utama 
Pada menu utama aplikasi Virtual Reality Wisata Edukasi terdapat 5 fitur yang dapat dipilih oleh pengguna,yaitu fitur Pengenalan Hewan Purba,Mengenal Huruf,Belajar Berkebun,Mengenal Angka,Belajar Sains

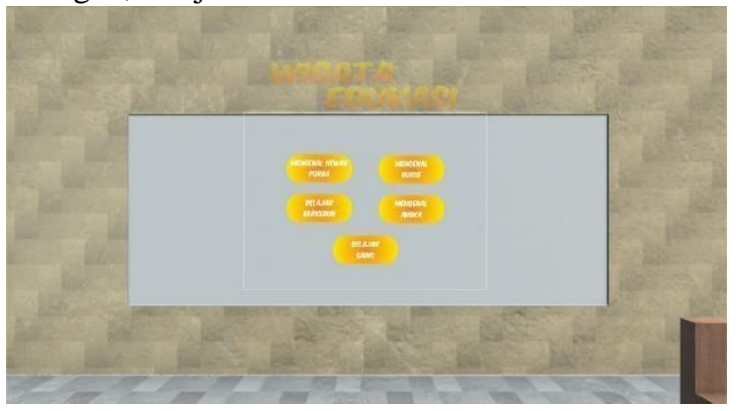

Gambar 4.1 Interface Menu Utama Aplikasi Virtual Reality Wisata Edukasi

2. Tampilan fitur Mengenal Hewan Purba

Pada fitur ini pengguna akan

mendapatkan informasi objek berupa bentuk hewan purba yang di tampilkan dengan animasi 3D,dan informasi nama- nama hewan purba melalui audio

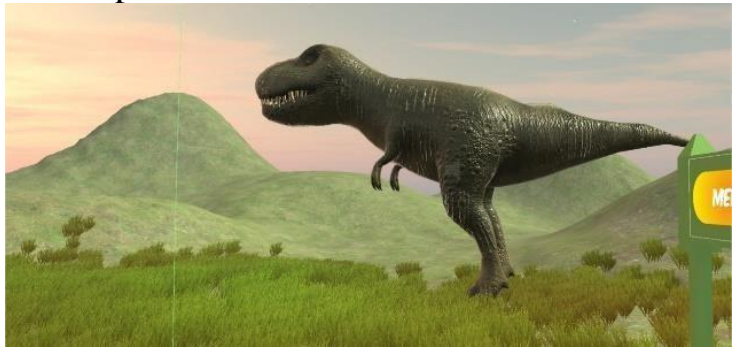

Gambar 4.2 Fitur Mengenal Hewan Purba

3. Tampilan fitur Mengenal Huruf

Pada fitur ini pengguna akan mendapatkan informasi objek berupa bentuk huruf-huruf yang di tampilkan dengan animasi 3D,dan informasi huruf melalui audio

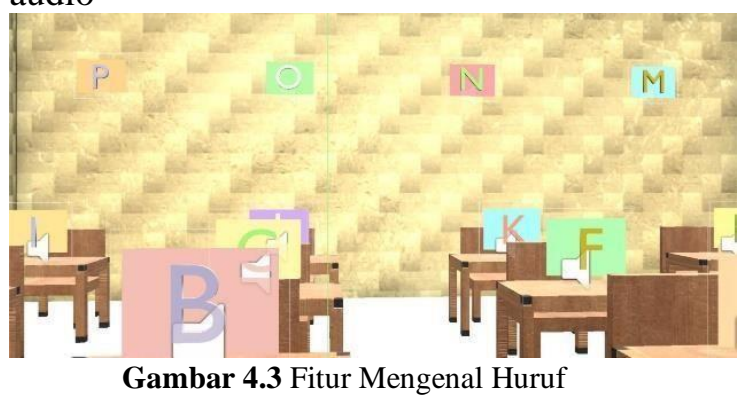

4. Tampilan fitur Belajar Berkebun

Pada fitur ini pengguna akan mendapatkan informasi objek berupa bentuk tanaman yang di tampilkan dengan animasi 3D,dan informasi tanaman melalui audio

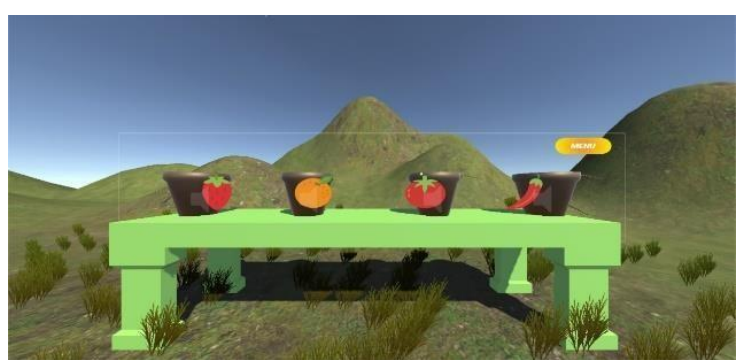

Gambar 4.4 Fitur Belajar Berkebun

5. Tampilan fitur Mengenal Angka

Pada fitur ini pengguna akan mendapatkan informasi objek berupa bentuk angka yang di tampilkan dengan animasi 3D,dan informasi angka melalui audio

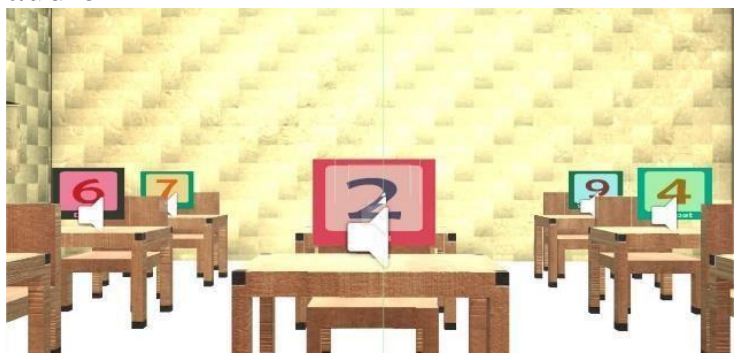

Gambar 4.5 Fitur Mengenal Angka

6. Tampilan fitur Belajar Sains

Pada fitur ini pengguna akan mendapatkan informasi objek berupa bentuk planet yang di tampilkan dengan animasi 3D,dan informasi planet melalui audio

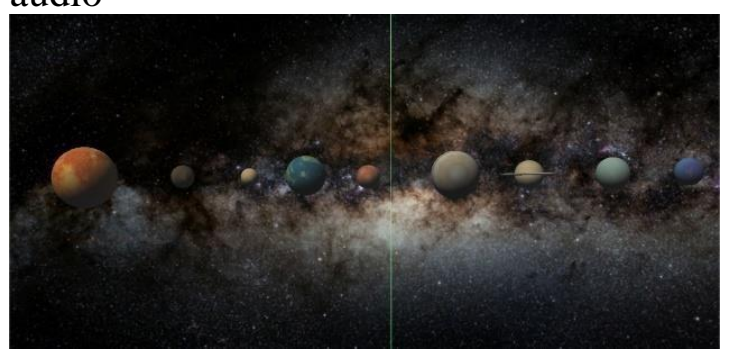

Gambar 4.5 Fitur Belajar Sains

7. Pembahasan

Pengujian yang dilakukan adalah pengujian fungsional aplikasi untuk menguji fungsi tombol menu dari aplikasi Virtual Reality Wisata Edukasi, pengujian ini bertujuan untuk mengetahui apakah semua tombol menu yang terdapat pada aplikasi dapat difungsikan. Serta pada bagian mode virtual reality sudah terkoneksi dengan joystick controller.

\begin{tabular}{ccccc}
\hline No. & $\begin{array}{c}\text { Nama } \\
\text { Pengujian }\end{array}$ & $\begin{array}{c}\text { Bentuk } \\
\text { Pengujian }\end{array}$ & $\begin{array}{c}\text { Hasil Yang } \\
\text { Diharapkan }\end{array}$ & Hasil \\
& & &
\end{tabular}




\begin{tabular}{|c|c|c|c|c|}
\hline 1. & $\begin{array}{c}\text { Membuka } \\
\text { Aplikasi }\end{array}$ & $\begin{array}{l}\text { Menekan } \\
\text { shortcut } \\
\text { aplikasi }\end{array}$ & $\begin{array}{c}\text { Sistem } \\
\text { menampilkan } \\
\text { menu utama }\end{array}$ & Berhasil \\
\hline 2. & $\begin{array}{c}\text { Pengujian } \\
\text { Tombol } \\
\text { Menu } \\
\text { Utama }\end{array}$ & $\begin{array}{c}\text { Menekan } \\
\text { Tombol } \\
\text { Mengenal } \\
\text { Hewan } \\
\text { Purba }\end{array}$ & $\begin{array}{c}\text { Sistem } \\
\text { Menampilkan } \\
\text { Mode } \\
\text { VirtualReality }\end{array}$ & Berhasil \\
\hline 3 & $\begin{array}{c}\text { Pengujian } \\
\text { Tombol } \\
\text { Menu } \\
\text { Utama }\end{array}$ & $\begin{array}{l}\text { Menekan } \\
\text { Tombol } \\
\text { Mengenal } \\
\text { Huruf }\end{array}$ & $\begin{array}{c}\text { Sistem } \\
\text { Menampilkan } \\
\text { Mode } \\
\text { VirtualReality }\end{array}$ & Berhasil \\
\hline 4 & $\begin{array}{c}\text { Pengujian } \\
\text { Tombol } \\
\text { Menu } \\
\text { Utama }\end{array}$ & $\begin{array}{l}\text { Menekan } \\
\text { Tombol } \\
\text { Belajar } \\
\text { Berkebun }\end{array}$ & $\begin{array}{c}\text { Sistem } \\
\text { Menampilkan } \\
\text { Mode } \\
\text { VirtualReality }\end{array}$ & Berhasil \\
\hline 5 & $\begin{array}{c}\text { Pengujian } \\
\text { Tombol } \\
\text { Menu } \\
\text { Utama }\end{array}$ & $\begin{array}{l}\text { Menekan } \\
\text { Tombol } \\
\text { Mengenal } \\
\text { Angka }\end{array}$ & $\begin{array}{c}\text { Sistem } \\
\text { Menampilkan } \\
\text { Mode } \\
\text { VirtualReality }\end{array}$ & Berhasil \\
\hline 6 & $\begin{array}{c}\text { Pengujian } \\
\text { Tombol } \\
\text { Menu } \\
\text { Utama }\end{array}$ & $\begin{array}{l}\text { Menekan } \\
\text { Tombol } \\
\text { Belajar } \\
\text { Sains }\end{array}$ & $\begin{array}{c}\text { Sistem } \\
\text { Menampilkan } \\
\text { Mode } \\
\text { VirtualReality }\end{array}$ & Berhasil \\
\hline 7 & $\begin{array}{c}\text { Pengujian } \\
\text { Tombol } \\
\text { Virtual } \\
\text { Reality }\end{array}$ & $\begin{array}{l}\text { Menekan } \\
\text { Tombol } \\
\text { Virtual } \\
\text { Reality }\end{array}$ & $\begin{array}{c}\text { Sistem } \\
\text { Menampilkan } \\
\text { Mode Virtual } \\
\text { Realiy }\end{array}$ & Berhasil \\
\hline 8 & $\begin{array}{c}\text { Pengujian } \\
\text { Tombol } \\
\text { Keluar }\end{array}$ & $\begin{array}{c}\text { Menekan } \\
\text { Tombol } \\
\text { Keluar }\end{array}$ & $\begin{array}{c}\text { Sistem Keluar } \\
\text { Aplikasi }\end{array}$ & Berhasil \\
\hline
\end{tabular}

\section{KESIMPULAN}

Penerapan Animasi 3 Dimensi Untuk Wisata Edukasi Berbasis Virtual Reality dapat memberikan pengalaman baru dalam perkembangan teknologi dengan menggunakan Virtual Reality. Aplikasi ini juga dapat menumbuhkan semangat belajar pengguna khusus nya anakanak,dalam aplikasi ini anak-anak dapat merasakan sensasi berinteraksi langsung dengan lingkungan yang telah di simulasikan

\section{UCAPAN TERIMA KASIH}

Saya mengucapkan banyak terima kasih kepada semua pihak yang telah banyak memberikan dorongan positif kepada penulis baik langsung maupun tidak langsung. penulis berharap semoga penelitian ini dapat berguna dan bermanfaat terutama bagi pihak-pihak yang tertarik untuk mengkaji dan mengembangkannya.

\section{REFERENSI}

[1] A, Haugstvedt and J. Krogstie.(2012). "Mobile Augmented Reality for Cultural Heritage: A Technology Acceptance Study"., IEEE International Symposium on Mixed and Augmented Reality (ISMAR), Atlanta, pp. 247-255.

[2] Gede Rasben Dantes, Komang Sudarma, Hendra Suputra.(2016). "Virtual Reality Dan Augmented Reality: Pemberdayaan Wisata Bawah Laut Dalam Rangka Meningkatkan Daya Dukung Pariwisata".,Seminar Nasional Vokasi dan Teknologi., ISSN Cetak : 25412361.

[3] Ossy Dwi Endah Wulansari, TM Zaini, Bobby Bahri.(2013).“Penerapan Teknologi Augmented Reality Pada Media Pembelajaran", Jurnal Informatika, Vol. 13, No.1.

[4] Radu, Iulian. (2014). "Augmented reality in education: A meta-review and cross-media analysis"., Article Personal and Ubiquitous Computing.18. 1533-1543.

[5] Robby Wijaya Khoerniawan, Ketut Agustini, I Made Putrama.(2018). "Game Edukasi Penjelajah Berbasis Virtual Reality"., Kumpulan Artikel Mahasiswa Pendidikan Teknik Informatika, Volume 7, No 1

[6] Rodger. D. (1998). Leisure, "learning and travel"., Journal of Physical Education, Research and Dance, 69(4), pp.28-31.

[7] Thadeo Angga Kusuma.(2017). "Pengembangan Media Pembelajaran Pengenalan Jenis-Jenis Ikan Berbasis Virtual Reality".,Tugas Akhir Jurusan Pendidikan Teknik Informatika: Universitas Pendidikan Ganesha.

[8] syahrir, Naim K, 2019, Rancang Bangun Augmented Reality Dengan Metode Markerless Studi Kasus Benda Museum Lagaligo Makassar, Seminar Nasional Hasil 
Jurnal Teknologi Elekterika. 2019, Volume 16 (1) : 33-38

Penelitian \& Pengabdian Kepada Masyarakat (SNP2M) 2018. 